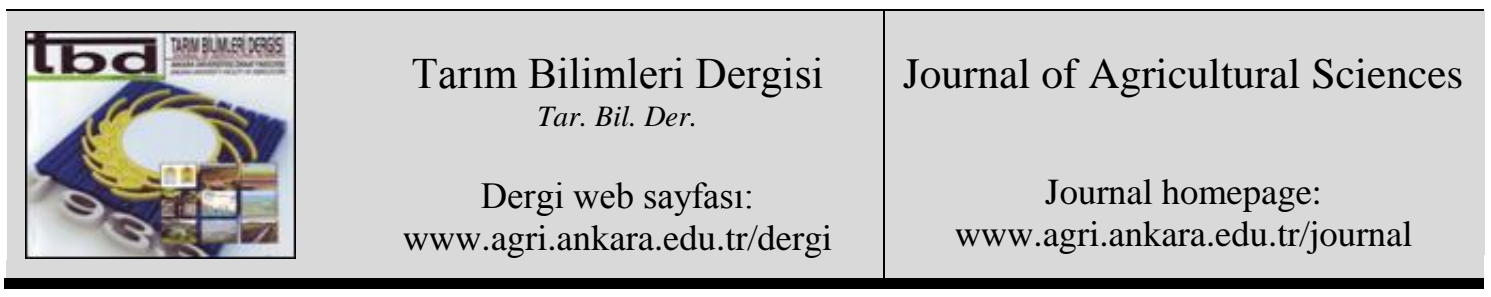

\title{
Members' Willingness to Invest Capital in the Agricultural Producer Unions: A Case of Samsun Province in Turkey
}

\author{
Bakiye KILIÇ TOPUZ ${ }^{\mathrm{a}}$

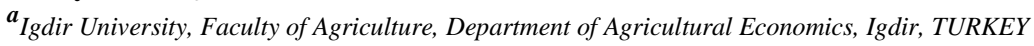

\section{ARTICLE INFO}

Research Article

Corresponding Author: Bakiye KILIÇ TOPUZ, E-mail: bakiyekilic@ @otmail.com, Tel: +90 (476) 2230010

Received: 20 May 2018, Received in Revised Form: 11 October 2018, Accepted: 27 November 2018

\author{
AUTHORS ORCID ID \\ (Bakiye KILIÇ TOPUZ: 0000-0002-3607-4306)
}

\begin{abstract}
The research aimed to reveal the members' willingness to invest capital in the Agricultural Producer Union (APU) and the factors influencing their decisions. The main data of the study obtained through the surveys from 420 members of the APU. Members' willingness to invest capital in their unions and effective factors were determined using the Contingent Valuation Method and the Random Effects Tobit model, respectively. The research revealed that $44 \%$ of the union members were willing to make an average contribution of 355 TL to their unions. Random Effects Tobit model results revealed that member's trust, membership fee,
\end{abstract}

participation in trainings, memberships of livestock union, apple and beekeeping, export crops through the union, attending the general assembly, level of education and agricultural experience positively affected the willingness to invest capital, while membership of the organic hazelnut and vegetables union, gender, management experience, age and total income negative affected the willingness to invest capital. In order to increase members' willingness to invest capital to their unions, members' trusts and participations in the training activities and administration of the unions should be increased.

Keywords: Willingness to invest capital; Agricultural producer union; Random effects Tobit model; Samsun

\section{Introduction}

(C) Ankara Üniversitesi Ziraat Fakültesi

Producers in the agricultural sector become members of agricultural organizations to meet their economic expectations such as providing agricultural inputs at a cheaper price, marketing their products more easily and at a higher price and increasing income and profitability (Karantininis \& Zago 2001; Hansen et al 2002; Österberg \& Nilsson 2009; Kılıç 2011; Kılıç Topuz 2017). Encouraging farmers to organize under farmer organizations and developing farmer organizations is stated as one of the prior issues and targets of agriculture policies in the main policy documents as $10^{\text {th }}$ Development Plan, Agricultural Law No. 5488 and the 2013-2017 Strategic Plan of Ministry of Food, Agriculture and Livestock (RG 2006; GTHB 2013; RG 2013). In Turkey, producers come together under the economic, social and professional organizations. While producers are organized within agricultural cooperatives, APU, grower unions, irrigation unions and agricultural foundations for economic and social purposes, they come together within the agricultural chambers and farmer association for professional purposes. A total of 11,480,690 farmers were members of 15,222 agricultural organizations in Turkey. The share of APU in agricultural organizations was 6\% (TRGM 2017). While the number of farmer organizations has increased in Turkey, they are not able to fulfill the functions expected from them (Özdemir et al 2010; Mülayim 2010). Capital insufficiency was stated as one of the main problems for the farmer organizations to provide sufficient and effective services 
to their members (Kaygusuzoğlu 2002; Şafaklı 2003; Rehber 2006; IRFO 2008; Mülayim 2010; Kılı̧̧ 2011; GTB 2012). Therefore, the farmer organization should have enough capital to provide sufficient services to their members. Membership share and fee constituted the most important legal income sources for agricultural producer organizations in Turkey (Kılıç Topuz et al 2017).

Reasons such as insufficiency of agricultural cooperatives in fulfilling the functions expected of them, problems of Agricultural Sales Cooperatives and their imposing a burden on the state budget, need for harmonization to the European Union's Common Agricultural Policy and lack of organizations for some crops or products have led to the emergence of APUs as a new organizational model in Turkey. APUs are legal entities in Turkey established voluntarily at the provincial or district level on the basis of crop or crop group a with the Law No 5200. APUs could get their income from membership fees, the share of services received from the sale price of the marketed products, wages from consultancy services provided to members, domestic and foreign donations, funds and aids, rents or revenues obtained from real estate, advertising, promotion and publications (RG 2004). APUs could not get enough capital through the mentioned income items and they could not provide sufficient services to their members. Therefore, it is of great importance that the members invest sufficient capital in the agricultural organizations.

The literature review revealed that only one research has been conducted about the willingness to invest capital in agricultural organizations (Newbery et al 2013). The study found that $87 \%$ of the members of the unions in England were willing to invest capital in their agricultural organizations and the willingness to invest capital was higher in the unions where the number of members and trust was higher. The Logit Regression model was used to determine the influential factors on investing capital. On the other hand, in Turkey, no study has been carried out on the willingness of the farmers to invest capital in their organizations. Therefore, this study aimed to reveal the members' willingness to invest capital in their unions and the factors influencing their investment decisions.

\section{Material and Methods}

\subsection{Material}

The main data was obtained from the surveys conducted April 2014-January 2015 with the members of 14 APUs in Samsun province, Turkey. As the sampling criterion, land property for the vegetable farms, animal assets for the livestock farms and the number of beehive for the beekeeping farm were used. Simple random sampling method was used (Equation 1) to determine the number of sample from the producer unions of organic hazelnut, vegetable, apple and beekeeping for which sampling criterion showed normal distribution. Stratified sampling method (Equation 2) was used to determine the number of sample from the producer unions of livestock and dairy cattle for which sampling criterion did not show normal distribution (Yamane 1967).

$\mathrm{n}=\frac{\mathrm{N}(\mathrm{zC})^{2}}{\mathrm{Nd}^{2}+(\mathrm{zC})^{2}}$

Where; $\mathrm{N}$ refers to the number of farmers, $\mathrm{z}$ is standard normal distribution value corresponding to desired trust level (1.645), $\mathrm{C}$ is variation coefficient (standard deviation/average), $\mathrm{d}$ is the error margin accepted in the research $\left({ }_{-}^{+} \% 10\right), \mathrm{n}$ is the number of samples required.

$\mathrm{n}=\frac{\mathrm{N} \cdot \sum\left(\mathrm{N}_{\mathrm{h}} \mathrm{S}_{\mathrm{h}}^{2}\right)}{\mathrm{N}^{2} \mathrm{D}^{2}+\sum\left(\mathrm{N}_{\mathrm{h}} \mathrm{S}_{\mathrm{h}}^{2}\right)}$

Where; $\mathrm{n}$ refers to the sample size, $\mathrm{N}$ is the number of units in the population, $\mathrm{N}_{\mathrm{h}}$ is the number of units in the $h^{\text {th }}$ layer, $S_{h}{ }^{2}$ is the variation of the $h^{\text {th }}$ layer. $D^{2}$ equals $\left(d^{2} / Z^{2}\right), d$ is the difference between the maximum amount of error or sample mean that can be accepted by the researcher and population while $\mathrm{z}$ refers to the $\mathrm{z}$ value in the standard normal distribution table according to the error margin. The study was based on 10\% error margin and 95\% confidence level and the number of samples was calculated as 420 . The adequacy of the sample number was tested by the Kaiser-Meyer-Olkin (KMO) sampling adequacy

Tarım Bilimleri Dergisi - Journal of Agricultural Sciences 26 (2020) 12-21 
measure and the Bartlett test. The KMO value was found to be 0.957 and the sample was determined to be high enough.

\subsection{Method}

Survey data were checked and then entered into the SAS 9.0 program to be analyzed. To determine the members' willingness to invest capital to their unions, Contingent Valuation Method (CVM) was used. CVM was widely used to determine willingness to pay for a specific feature (Mitchell \& Carson 1989; Garrod \& Willis 1990). The reliability of the survey was tested by reliability analysis, the members' response consistency to the survey questions was measured by the Cronbach Alpha approach and the research was found to be highly reliable (0.724). The members were asked that when the union increase net return of the farm at different amount (e.i. 0 TL, 1000 TL, $2000 \mathrm{TL}, \ldots, 10,000 \mathrm{TL}$ ), how much capital would you willing to invest to your union in each situation. With CVM, the level of respondents' willingness to pay based on assumption can be higher than what they pay in real life. Therefore, the respondents were also asked how sure they were on willingness to invest capital to the union (1: Not sure at all, .. 10: definitely sure). Subsequently, it was accepted that the members were willing to invest capital to the union when the sureness level of member was 8 and above. The NLOGIT 5.0 package program was used to estimate the model of the study. Panel data was used in the study. There are union members in the horizontal section while in the time dimension, there are the amounts of the willingness to pay for the increment in the offer amount of each thousand \$ for the amount of 11 proposals presented to each member $(0,1000,2000,3000, \ldots, 10,000 \mathrm{TL})$.

In the following, the base Tobit model proposed by Tobin (1958) will be adopted as the starting point to study the left-censored crash rate data. Under panel data formation, repeated observations are given for each group. As discussed above, correlations may exist among these repeated observations. A Tobit model with random effects is therefore proposed as it is capable of accounting for both censoring effects and serial correlations. The random effects Tobit model is applied to account for such correlations across observations in addition to unobserved heterogeneity. In the present study, random effects Tobit model is developed based on a typical left-censored Tobit model (with a lower limit of zero). A baseline structure for a leftcensored Tobit model with panel data can be described as follows:

$Y_{i t}^{*}=X_{i t} \beta+\varepsilon_{i t}, i=1, \ldots, N, t=1, \ldots, T_{i}$ and

$Y_{i t}=Y_{i t}^{*}$ if $Y_{i t}^{*}>0$

$Y_{i t}=0$ if $Y_{i t}^{*} \leq 0$

Where; $\mathrm{N}$ is the number of members, $\mathrm{t}$ is the number of the repeated offer amount $(0,1000,2000,3000$, $\ldots, 10,000 \mathrm{TL}$ ), $\mathrm{Y}_{\mathrm{it}}$ is the dependent variable (willingness to invest capital, WTI) and $Y_{i t}^{*}$ is the latent variable observed only when positive. $\mathrm{X}_{\mathrm{it}}$ is a vector of explanatory variables, $\beta$ is a vector of estimable coefficients, and $\varepsilon_{i t}$ is the error term.

The essential assumption for the random effects Tobit model to distinguish it from its fixed effects counterpart is that the heterogeneity (i.e. random effects) is assumed to be uncorrelated with the independent variables $\mathrm{X}_{\mathrm{it}}$. Thus, the corresponding log-likelihood function for the random effects Tobit model is derived by obtaining the unconditional density through integrating the random effects $\mu_{\mathrm{i}}$ out of the conditional density (Greene 2012):

$f\left(Y_{i t} I X_{i t}, \mu_{i} ; \theta\right)=\prod_{Y_{i t}>0 \sigma_{v}} \frac{1}{\sigma_{v}} \varphi\left(\frac{Y_{i t} X_{i t} \beta-\mu_{i}}{\sigma_{v}}\right) \prod_{Y_{i t}=0} \phi\left(\frac{-X_{i t} \beta-\mu_{i}}{\sigma_{v}}\right)$

The panel level likelihood $l_{i}$ is given by 


$$
\begin{aligned}
l_{i} & =\int_{-\infty}^{\infty} \frac{e^{-\frac{v_{i}^{2}}{2 \sigma_{v}^{2}}}}{\sqrt{2 \pi \sigma v}}\left\{\prod_{t=1}^{n_{i}} F\left(Y_{i t}^{*}, X_{i t} \beta+v_{i}\right)\right\} d v_{i} \\
& \equiv \int_{-\infty}^{\infty} g\left(Y_{i t}^{*}, X_{i t}, v_{i}\right) d v_{i}
\end{aligned}
$$

Where; $\varphi(*)$ is standard normal density function; $\varphi(*)$ is standard normal distribution function.

Both Gauss-Hermite quadrature and simulation-based maximum likelihood estimations can be adopted to get the maximum of the log-likelihood function of random effect models (Greene 2012). The first approach gives approximated estimation in which the estimation accuracy is partly determined by the integration points used. Random effects Tobit model can be viewed as a special case of random parameter Tobit model, in which only the constant term is treated as a random parameter (Anastasopoulos \& Mannering 2009; Lord \& Mannering 2010) and simulation-based maximum likelihood estimation can be exploited to solve the log-likelihood function.

From the data described in the previous section, the final random-effects Tobit model estimated in this study was shown by the Equation 6:

$$
\begin{aligned}
& \text { WTI }=\beta_{0}+\beta_{1} \text { TRUST }_{\text {it }}+\beta_{2} \text { STOCK }_{\text {it }}+\beta_{3} \text { APPLE }_{i t}+\beta_{4} \text { BEEKPNG }_{\text {it }}+\beta_{5} \text { VEGETAB }_{\text {it }}+\beta_{6} \text { ORGHAZEL }_{i t}+ \\
& \beta_{7} \text { CAPITAL }_{i t}+\beta_{8} \text { JOINEDU }_{\text {it }}+\beta_{9} \text { EXPORT }_{\text {it }}+\beta_{10} \text { GENMEET }_{\text {it }}+\beta_{11} \text { DISTANC }_{\text {it }}+\beta_{12} \text { SUPINPUT }_{\text {it }}+\beta_{13} \text { MARKE } \text { MAR }_{17} \\
& \text { TNG }_{i t}+\beta_{14} \text { MANAGEXP }_{\text {it }}+\beta_{15} \text { VISITFRE }_{\mathrm{it}}+\beta_{16} \text { PERFORMC }_{\mathrm{it}}+\beta_{17} \mathrm{FRS}_{\mathrm{it}}+\beta_{18} \text { NUMORG }_{\mathrm{it}}+\beta_{19} \text { INSURANC }_{\mathrm{it}}+ \\
& \beta_{20} \text { HSIZE }_{i t}+\beta_{21} \text { INCOME }_{\text {it }}+\beta_{22} \text { MARSTAT }_{\text {it }}+\beta_{23} \text { SOCSEQUR }_{i t}+\beta_{24} \text { MAINPROF }_{i t}+\beta_{25} \text { EDUCAT }_{i t}+\beta_{26} \text { EXPE } \\
& \mathrm{RIEN}_{\mathrm{it}}+\beta_{27} \mathrm{GENDER}_{\mathrm{it}}+\beta_{28} \mathrm{AGE}_{\mathrm{it}}+\varepsilon_{\mathrm{it}}
\end{aligned}
$$

In research, the variables that were thought to be effective on members' willingness to invest capital were selected. For example, if members' income change, members' willingness to invest capital can change. Similarly, product marketing or supply input through union can cause members' willingness to invest capital.

\section{Results and Discussion}

\subsection{Descriptive results}

The average capital of APUs was 196 thousand TL ( $\$ 89.4$ thousand $^{1}$ ). APUs obtained $40.7 \%$ of their capital from membership fees. The other main income sources were agricultural support deductions $(25.8 \%)$, consultancy services $(23 \%)$, marketing of the crops or products $(6.8 \%)$, real estate sales or rents $(1.5 \%)$ and donations, funds and subsidies $(1.4 \%)$. Dairy cattle and livestock producer unions have the highest equity capital due to the deductions from animal husbandry subsidies. About $86 \%$ of the unions had a capital insufficiency problem. APUs had averagely 612 members.

Descriptive statistics was given in Table 1. Research results revealed that the members were willing to invest capital an average of $154 \mathrm{TL}(\$ 70.3)$ in their union. Of the farmers interviewed 36\% were from dairy cattle, $22 \%$ from organic hazelnut, $16 \%$ from livestock, $14 \%$ from vegetables, $10 \%$ from beekeeping and $2 \%$ from apple agricultural producer unions. Ninety-eight percent of the union members were male and the average age of the members was 50. Average education period was 6 years and $68 \%$ and $13 \%$ of the members graduated from primary and secondary school, respectively. Ninety-four percent of the members stated their main profession as farmer and their agricultural experience was 27 years. The average number of households was 4.88 persons.

\footnotetext{
${ }^{1} 2.19$ Turkish Liras $=\$ 1$ (average exchange rate of dollar in 2014)
} 
The average performance index of the unions was $43.5 \%$. The average trust level of the members to the union, executive board and other members was 3.17. Only $21 \%$ and $15 \%$ of the members marketed and exported their crops through the unions, respectively. The respondents were averagely members of two farmer organizations and majority of them $(85 \%)$ paid fully their entrance fees to the unions. While only $5 \%$ of members provide input from their unions, and $32 \%$ of them participated in the trainings of the union. Research conducted in the South Eastern Anatolia Project by Karl1 \& Çelik (2003) revealed that 40.7\% of the members provided inputs from agricultural organizations, $28 \%$ and $15.6 \%$ of them marketed their products and participated in training activities. The average distance between the members' farms and the unions was $13 \mathrm{~km}$ and the members visited their unions 51 times in a year. The VIF values of the independent variables used in the model are less than 20 and this indicates that there were no multiple correlations between the independent variables.

Table 1- Descriptive statistics of the variables of the models

\begin{tabular}{|c|c|c|c|c|c|}
\hline Variables & Definition of the variables & $N$ & Mean & Std. dev. & VIF \\
\hline \multicolumn{6}{|c|}{$\underline{\text { Dependent variable }}$} \\
\hline WTIC & Willingness to invest capital (TL) & 4,620 & 154.86 & 313.03 & - \\
\hline \multicolumn{6}{|c|}{ Independent variables } \\
\hline \multicolumn{6}{|l|}{$\underline{\text { Union variables }}$} \\
\hline TRUST & $\begin{array}{l}\text { Trust index for the union, executive board and other members } \\
\text { (1: The lowest, } \ldots, 5: \text { The highest) }\end{array}$ & 4,620 & 3.17 & 1.21 & 1.72 \\
\hline STOCK & $=1$ if the respondent is a member of livestock; 0 otherwise & 4,620 & 0.16 & 0.37 & 1.81 \\
\hline APPU & $=1$ if the respondent is a member of apple; 0 otherwise & 4,620 & 0.02 & 0.16 & 1.34 \\
\hline BEEKU & $=1$ if the respondent is a member of beekeeping; 0 otherwise & 4,620 & 0.10 & 0.29 & 1.64 \\
\hline VEGU & $=1$ if the respondent is a member of vegetables; 0 otherwise & 4,620 & 0.14 & 0.34 & 2.20 \\
\hline OHAZU & $=1$ if the respondent is a member of organic hazelnut; 0 otherwise & 4,620 & 0.22 & 0.41 & 3.25 \\
\hline CAPITAL & $=1$ if the respondent paid entrance capital to union; 0 otherwise & 4,620 & 0.85 & 0.36 & 1.16 \\
\hline ATTEXT & $=1$ if the respondent participated in the trainings; 0 otherwise & 4,620 & 0.32 & 0.47 & 1.72 \\
\hline EXPORT & $=1$ if the respondent exported through union; 0 otherwise & 4,620 & 0.15 & 0.35 & 2.98 \\
\hline GENAS & $=1$ if the respondent attended general assembly; 0 otherwise & 4,620 & 0.60 & 0.49 & 1.66 \\
\hline DISTAN & Distance between farm and union $(\mathrm{km})$ & 4,620 & 13.30 & 9.88 & 1.41 \\
\hline SUPPINP & $=1$ if the respondent supplied input from union; 0 otherwise & 4,620 & 0.05 & 0.21 & 1.38 \\
\hline MARKETNG & $=1$ if the respondent marketed product through union; 0 otherwise & 4,620 & 0.20 & 0.40 & 2.08 \\
\hline EXPER & $\begin{array}{l}=1 \text { if the respondent had experience of union-management; } 0 \\
\text { otherwise }\end{array}$ & 4,620 & 0.08 & 0.28 & 1.23 \\
\hline VISIT & Frequency of visiting union (times year ${ }^{-1}$ ) & 4,620 & 51.52 & 98.37 & 1.42 \\
\hline PERFOR & Performance index of the union $(\%)$ & 4,620 & 43.55 & 8.08 & 1.67 \\
\hline \multicolumn{6}{|l|}{$\underline{\text { Farm variables }}$} \\
\hline FRS & $\begin{array}{l}=1 \text { if the member is registered to the Farmer Registration System; } \\
0 \text { no; } 2 \text { no land }\end{array}$ & 4,620 & 1.08 & 0.41 & 1.22 \\
\hline NUMORG & The number of agricultural organization membership (unit) & 4,620 & 2.13 & 0.97 & 1.46 \\
\hline INSUR & $=1$ if the respondent had agriculture insurance; 0 otherwise & 4,620 & 0.18 & 0.39 & 1.40 \\
\hline HSIZE & Household size (person) & 4,620 & 4.88 & 2.46 & 1.29 \\
\hline INCOME & Total income of member (TL years $\left.{ }^{-1}\right)$ & 4,620 & 91.45 & 119.26 & 1.45 \\
\hline \multicolumn{6}{|c|}{ Members variables } \\
\hline MARITS & $=1$ if the respondent is married; 0 single & 4,620 & 0.95 & 0.22 & 1.14 \\
\hline SOCSEC & $=1$ if the respondent had social security; 0 no & 4,620 & 0.91 & 0.28 & 1.15 \\
\hline PROFES & $=1$ if the respondent's main profession is agriculture; 0 otherwise & 4,620 & 0.94 & 0.24 & 1.21 \\
\hline EDUC & Education status of the member (years) & 4,620 & 6.25 & 2.96 & 1.39 \\
\hline EXPER & Agricultural experience of the member (years) & 4,620 & 27.55 & 13.51 & 2.45 \\
\hline GENDER & $=1$ if male; 0 female & 4,620 & 0.98 & 0.14 & 1.11 \\
\hline AGE & Age of member (years) & 4,620 & 50.14 & 11.63 & 2.57 \\
\hline
\end{tabular}


In Turkey, farmers are obliged to pay the designated entry fee to become a member of APUs. Members are also obliged to pay annual dues for each year. Membership entrance fees cannot be less than $10 \%$ and more than half of the gross amount of the monthly minimum wage (RG 2004). The members' willingness to invest capital in their unions was given in Table 2 . The results show that $44 \%$ of the members were willing to provide a high level of capital contribution to their unions if the unions increase net income of the farms. Newbery et al (2013) determined that 87\% of the members in England were willing to invest capital for the survival of their union.

It was determined that if the unions do not make any additional contribution to the farm's income, the members were willing to invest an average capital of $116 \mathrm{TL}$ (\$52.9). The members were willing to invest capital of $151.5 \mathrm{TL}$ (\$69) (15.1\% of the income increase provided), in return for the union's provision of an increment of $1,000 \mathrm{TL}(\$ 456)$ in the farm's income. If the income increment is $10,000 \mathrm{TL}(\$ 4,566)$, the members were willing to invest capital of $600 \mathrm{TL}$ (\$274) (6\% of the income increase provided) to their union.

Table 2- The members' willingness to invest capital

\begin{tabular}{|c|c|c|c|c|c|c|c|c|c|c|c|c|}
\hline & \multicolumn{12}{|c|}{ The increment provided by the union to the members' net profit (TL) } \\
\hline & 0 & 1,000 & 2,000 & 3,000 & 4,000 & 5,000 & 6,000 & 7,000 & 8,000 & 9,000 & 10,000 & Mean \\
\hline $\begin{array}{l}\text { Frequency of } \\
\text { WTIC }(\%)\end{array}$ & 32.9 & 44.0 & 44.5 & 44.8 & 46.4 & 46.7 & 44.5 & 42.9 & 42.9 & 42.9 & 42.9 & 44.2 \\
\hline $\begin{array}{l}\text { Average } \\
\text { WTIC (TL) }\end{array}$ & 116.0 & 151.5 & 204.1 & 256.3 & 310.9 & 362.3 & 400.9 & 453.3 & 502.4 & 546.2 & 600.1 & 354.94 \\
\hline
\end{tabular}

Depending on the increase of 1,000 TL (\$456) that the union will provide to the income of the farm, the capital that the members were willing to invest in their union changed between 35.5 TL (\$16.2) and 54.6 TL (\$24.9) (average 48.4 TL). Considering the fact that APUs had an average of 612 members and a capital of 196 thousand TL ( $\$ 90$ thousand), it can be understood that for each increment of 1,000 TL (\$456) that the union will provide to their members, a total of 40 thousand TL ( $\$ 18$ thousand) $(20.4 \%$ ) will be added to the total equity of the union; 103 thousand TL ( $\$ 47$ thousand) $(52.6 \%)$ for an increment of 5,000 TL $(\$ 2,283)$ and 158 thousand TL (\$72 thousand) (80.6\%) for an increment of 10,000 TL $(\$ 4,566)$. These results imply that there may be an increase of $20.4 \%$ to $80.6 \%$ in the equity of the unions in return for the incomes that they provide to their members. In addition, the increased equity capital in the unions will also facilitate the possibility of external financing

\subsection{Random effects Tobit model results}

The estimation results of the Random Effects Tobit model was given in Table 3. Estimated Tobit model results indicated that there was a statistically significant positive relationship between the variables of trust, entrance fee payment, participation in trainings, being a member of the livestock union, marital status, being a member of the apple agricultural producer union, exporting through union, social security, attending the general assembly, being a farmer, the number of farmer organization membership, being a member of the beekeeping union, distance to the union, educational status and agricultural experience and the members' willingness to invest capital. On the other hand, there was a statistically negative relationship between the variables of input supply, membership to the vegetable and organic hazelnut unions, gender, management experience, insurance, marketing crops tough the union, household size, age, total income, frequency of visiting the union and the members' willingness to invest capital in their unions.

The Tobit model results show that the members can increase their capital contribution to their unions by 340 TL (\$155) with a 1 unit increase in trust index. That is, as the members' trust to their unions, union executive board and other members increase, their capital contribution to their unions would be increased. Şafaklı (2003) showed that less trust in the organizations caused capital shortage. Newbery et al (2013) found also that there was a positive relationship between the members' trust and the members' willingness to invest capital to their organizations. On the contrary, Kovacic et al (2000) found that there was no statistically significant effect between the trust and the farmers' willingness to cooperate. Capital insufficiency and distrust were determined as the most important problems in agricultural organizations. In

Tarım Bilimleri Dergisi - Journal of Agricultural Sciences 26 (2020) 12-21 
order to increase the amount of capital which is one of the most important elements in the success of the unions, the members' trust to their unions, executive board and other members should be established and increased.

The members' willingness to invest capital to the livestock union was 390 TL (\$178) higher than the dairy cattle union. The members' willingness to invest capital in the apple agricultural producer union was 247 TL (\$113) than the dairy cattle producer union. The members' willingness to invest capital in the beekeeping producer union was 57 TL (\$26) higher than the dairy cattle producer union. On the other hand, the members' willingness to invest capital in the vegetable producer union was 286 TL (\$130) less than the dairy cattle producer union while the members' willingness to invest capital to the organic hazelnut producer union was $426 \mathrm{TL}$ (\$195) less than the dairy cattle producer union.

The member participated in the general assembly of unions were willing to invest 153 TL (\$70) more to their unions when compared to their counterparts. Participation levels of the members to the unions was not common. Therefore, the unions should increase their participation in general assembly meetings. Phillipson et al (2006) stated also that unions typically suffer from poor attendance at meetings and weak participation in other activities of the union.

Table 3- Random Effects Tobit model of willingness to invest capital

\begin{tabular}{|c|c|c|c|c|c|}
\hline \multirow{2}{*}{\multicolumn{2}{|c|}{ Independent variables }} & \multirow{2}{*}{$\begin{array}{l}\text { Tobit model } \\
\text { coefficient }\end{array}$} & \multicolumn{3}{|c|}{ Marginal effects } \\
\hline & & & Coefficient & Elasticities & z-value \\
\hline \multirow{2}{*}{\multicolumn{2}{|c|}{$\begin{array}{l}\text { Constant } \\
\text { Constant }\end{array}$}} & $-2842.71 * * *$ & - & - & - \\
\hline & & $686.472 * * *$ & - & - & - \\
\hline \multirow{16}{*}{$\begin{array}{l}\text { Union } \\
\text { variables }\end{array}$} & TRUST & $339.684 * * *$ & $115.285 * * *$ & 5.09 & 2.85 \\
\hline & STOCK & $390.244 * * *$ & $132.445 * * *$ & 0.29 & 2.76 \\
\hline & APPU & $247.358 * * *$ & $83.9509 * * *$ & 0.03 & 2.66 \\
\hline & BEEKU & $57.0525 * *$ & $19.3630 * *$ & 0.02 & 1.63 \\
\hline & VEGU & $-286.339 * * *$ & $-97.1807 * * *$ & -0.18 & -2.75 \\
\hline & OHAZU & $-426.474 * * *$ & $-144.741 * * *$ & -0.44 & -2.85 \\
\hline & CAPITAL & $709.968 * * *$ & $240.956 * * *$ & 2.84 & 2.89 \\
\hline & ATTEXT & $422.519 * * *$ & $143.399 * * *$ & 0.64 & 2.78 \\
\hline & EXPORT & $211.701 * * *$ & $71.8491 * * *$ & 0.14 & 2.64 \\
\hline & GENAS & $153.715 * * *$ & $52.1692 * * *$ & 0.43 & 2.62 \\
\hline & DISTAN & $32.0513 * * *$ & $10.8779 * * *$ & 2.01 & 2.79 \\
\hline & SUPPINP & $-590.982 * * *$ & $-200.573 * * *$ & -0.13 & -2.75 \\
\hline & MARKETNG & $-82.7980 * * *$ & $-28.1008 * *$ & -0.07 & -2.34 \\
\hline & EXPER & $-142.228 * * *$ & $-48.2706 * * *$ & -0.05 & -2.60 \\
\hline & VISIT & $-0.22209 * * *$ & $-0.07537 * *$ & -0.05 & -2.11 \\
\hline & PERFOR & 0.19670 & 0.06676 & 0.04 & 0.21 \\
\hline \multirow{5}{*}{$\begin{array}{l}\text { Farm } \\
\text { variables }\end{array}$} & FRS & 208.646 & 7.08124 & 0.10 & 1.23 \\
\hline & NUMORG & $93.7519 * * *$ & $31.8184 * * *$ & 0.94 & 2.78 \\
\hline & INSUR & $-99.5203 * * *$ & $-33.7762 * *$ & -0.08 & -2.47 \\
\hline & HSIZE & $-20.2047 * * *$ & $-6.85728 * *$ & -0.46 & -2.42 \\
\hline & INCOME & $-0.55725 * * *$ & $-0.18913 * * *$ & -0.24 & -2.65 \\
\hline \multirow{7}{*}{$\begin{array}{l}\text { Member } \\
\text { variables }\end{array}$} & MARITS & $364.809 * * *$ & $123.813 * * *$ & 1.63 & 2.93 \\
\hline & SOCSEC & $155.926 * * *$ & $52.9198 * * *$ & 0.67 & 2.78 \\
\hline & PROFES & $100.248 * * *$ & $34.0230 * *$ & 0.44 & 2.50 \\
\hline & EDUC & $31.5024 * * *$ & $10.6916 * * *$ & 0.93 & 2.94 \\
\hline & EXPER & $4.81106 * * *$ & $1.63283 * * *$ & 0.62 & 2.60 \\
\hline & GENDER & $-288.318 * * *$ & $-97.8522 * *$ & -1.33 & -2.31 \\
\hline & AGE & $-4.35089 * * *$ & $-1.47665 * *$ & -1.03 & -2.18 \\
\hline \multirow{2}{*}{\multicolumn{2}{|c|}{$\begin{array}{l}\text { Log-Likelihood } \\
\mathrm{N}\end{array}$}} & -15460.71078 & & & \\
\hline & & 4.620 & & & \\
\hline
\end{tabular}

** and $* * *$ indicates statistically significant at the level of $5 \%$ and $1 \%$, respectively 
Members who paid full entrance fee were willing to invest 709 TL (\$324) more capital to their unions when compared to those who did not pay. Members who participated in the trainings of the unions were willing to invest $422 \mathrm{TL}$ (\$192) more capital to their unions when compared to those who did not participate. Members who had one year higher education were willing to invest 31 TL (\$14) more capital to their unions when compared to their counterparts. Members who exported their crops through the union were willing to invest $211 \mathrm{TL}$ (\$96) more capital to their unions when compared to their counterparts. Female and one year younger members were willing to invest $288 \mathrm{TL}(\$ 131)$ and $4 \mathrm{TL}(\$ 1.8)$ higher capital, respectively when compared to their counterparts.

When the marginal effects of the explanatory variables in the Tobit model are evaluated, $1 \%$ increase in trust level of the members would lead to a 5.09\% increase in willingness to invest capital. The members who totally paid entrance fee were willing to invest capital was $2.84 \%$ higher than their counterparts. The members who participated in the trainings of the union was $0.64 \%$ higher than their counterparts. The female and one year younger members were willing to invest $1.33 \%$ and $1.03 \%$ higher capital than their counterparts.

\section{Conclusions}

In this study, levels of willingness to invest capital were found as moderate level. There was a positive relationship between the variables of trust, participation in trainings and general assembly, paying entrance fees and exporting crops through the union and the members' willingness to invest capital to the unions.

When the unions increase the income of their members, the members would provide 40-158 thousand TL (\$18.2-72.1 thousand) to their unions. In order to increase the willingness of the members to invest capital in the unions; the unions should increase the incomes of their members. This can also increase the members' willingness to provide capital to their unions. Trust had very high impacts on the members' willingness to invest capital to the unions. In order to increase the capital of the unions, it is of great importance that the members' trust the unions should be increased. In order to increase the trust of the members, the producer unions should take an active role in marketing products or crops and supply input. Increasing the participation of members in the trainings organized by the unions could help to increase capital investment of the members. Therefore, it is of great importance that the unions should organize training programs according to the needs of members and each member should be encouraged to participate in these training programs. If the unions sell their members' crops or products to the foreign markets, this will encourage member merchant cooperativeness. Exporting members' crops or products to foreign markets would increase capital accumulation in the unions by the members. As the members older, they were willing to provide less capital to their unions. Therefore, raising awareness of older members on the benefits of capital accumulation in the unions and encouraging young farmers on being a member of the unions would increase capital accumulation in the unions. Moreover, the members should actively participate in the governance of the unions to increase capital of the unions. This study concluded also that this study should expand to other farmer unions in the regional or country levels.

\section{Acknowledgements}

I would like to thank the members and executive boards of Agricultural Producer Unions in Samsun province for their valuable contributions to this research.

\section{References}

Anastasopoulos P C \& Mannering F L (2009). A note on modeling vehicle accident frequencies with randomparameters count models. Accident Analysis \& Prevention 41(1): 153-159

Garrod G \& Willis K G (1990). Contingent valuation techniques: a review of their unbiasedness, efficiency and consistency. Countryside Change Initiative Working Paper 10. Newcastle: University of Newcastle upon Tyne

Greene W (2012). Limdep, Version 10.0. Econometric Software, Inc., Plainview, NY

Tarım Bilimleri Dergisi - Journal of Agricultural Sciences 26 (2020) 12-21 
GTB (2012). Gümrük ve Ticaret Bakanlığı Kooperatifçilik Genel Müdürlüğü, Türkiye kooperatifçilik stratejisi ve eylem planı 2012-2016, Ankara

GTHB (2013). Gıda, Tarım ve Hayvancılık Bakanlığı 2013-2017 stratejik planı, Ankara

Hansen M, Morrow J \& Batista J C (2002). The impact of trust on cooperative membership retention, performance and satisfaction: an exploratory study. The International Food and Agribusiness Management Review 5(1): 41-59

IRFO (2008). Çiftçi örgütlerinin kurumsal güçlendirilmesi projesi, Uygulama ve tamamlama raporu, Türkiye ormancılık kooperatifleri merkez birliği

Karantininis K \& Zago A M (2001). Endogenous membership in mixed duopsonies. American Journal of Agricultural Economic 83(5): 1266-1272

Karlı B \& Çelik Y (2003). GAP alanındaki tarım kooperatifleri ve diğer çiftçi örgütlerinin bölge kalkınmasındaki etkinliği. Tarımsal Ekonomi Araştırma Enstitüsü, Yayın No: 97, ISBN: 975-407-122-5

Kaygusuzoğlu M (2002). Ekonomik krizden çıkışta mooperatifçilik, Karınca kooperatif postası, Türk kooperatif̧cilik kurumu, Ankara

Kılıç B (2011). Samsun ilindeki tarımsal kalkınma kooperatiflerinde ortak-kooperatif ilişkilerinin analizi. Yüksek lisans tezi, Ondokuz Mayıs Üniversitesi Fen Bilimleri Enstitüsü, Samsun (Yayınlanmış)

Kılıç Topuz B (2017). Samsun ili tarımsal üretici birliklerinde güven ve performansa etkili faktörler. Doktora tezi, Ondokuz Mayıs Üniversitesi Fen Bilimleri Enstitüsü (Basılmamış), Samsun

Kılıç Topuz B, Bozoğlu M \& Başer U (2017). Güncel gelişmeler kapsamında Türkiye'deki çiftçi örgütlerine yönelik mevzuatın değerlendirilmesi. Üçüncü Sektör Sosyal Ekonomi Dergisi, 52(Özel sayı): 140-161

Kovacic D, Juracak J \& Zutinic D (2000). Willingness of farmers to cooperate field study results in the Zagreb rural area. Portal Znanstventh Casopisa Republike Hrvatskb 6(56): 1119-1129

Lord D \& Mannering F (2010). The statistical analysis of crash-frequency data: a review and assessment of methodological alternatives. Transportation Research Part A: Policy Practice 44(5): 291-305

Mitchell R C \& Carson R T (1989). Using Surveys to Value Public Goods: The Contingent Valuation Method. Resources for the Future, Washington DC

Mülayim Z G (2010). Kooperatifçilik. Yetkin Yayınları, Ankara

Newbery R, Sauer J, Gorton M, Phillipson J \& Atterton J (2013). Determinants of the performance of business associations in rural settlements in the United Kingdom: an analysis of members' satisfaction and willingness-topay for association survival, Environment and Planning 45: 967-985

Österberg P \& Nilsson J (2009). Members' perception of their participation in the governance of cooperatives: the key to trust and commitment in agricultural cooperatives. Agribusiness 25(2): 181-197

Özdemir G, Keskin G \& Özüdoğru H (2010). Türkiye'de ekonomik krizlere alternatif bir çözüm önerisi: tarımda güçlü ve etkin üretici örgütlenme modeli. IX. Tarım Ekonomisi Kongresi, 22-24 Eylül, Şanlıurfa, s. 518-525

Phillipson J, Gorton M \& Laschewski L (2006). Local business co-operation and the dilemmas of collective action: rural micro-business networks in the north of England. Sociologia Ruralis 46: 40-60

Rehber E (2006). Tarımda yeni nesil kooperatifler. Tarım ve Köy İşleri Bakanlığı, Türktarım Dergisi 171: 40-43

RG (2004). 29.06.2004 tarih 25514 Sayılı Resmi Gazete, Tarımsal Üretici Birlikleri Kanunu. http://www.resmigazete. gov.tr/eskiler/2004/07/20040706.htm\#2 (Erişim tarihi: 11.01.2018)

RG (2006). Tarım Kanunu, 18.04.2006 tarih 5488 Sayılı Kanun, http://www.resmigazete.gov.tr/eskiler/2006/ 04/20060425-1.htm (Erişim tarihi: 10.01.2018) 
RG (2013). 06.07.2013 tarih 28699 Say1l Kanun, 10. Kalkınma Planı, http://www.resmigazete.gov.tr/eskiler/2013/07/ 20130706M1-1.htm (Erişim tarihi: 02.02.2018)

Şafaklı O (2003). KKTC'de kooperatiflerin finansmanı üzerine bir çalışma. Yönetim ve Ekonomi 10(2): $175-189$

TRGM (2017). Tarım Reformu Genel Müdürlügü, Tarımsal örgütlenme tablosu. http://www.tarim.gov.tr/TRGM/ Belgeler/Tarimsal Örgütlenme Tablosu (Erişim tarihi: 18.12.2017)

Tobin J (1958). Estimation of relationships for limited dependent variables. Econometrica 26(1): 24-26

Yamane T (1967). Elemantary Sampling Theory. Prentice Hall Inc., Englewoods, New Jersey 